Excellence
inHigher
Excellence in Higher Education 1 (2010): 23-30

\title{
The Development of Context-Based English Learning Resources for Elementary Schools in Central Java
}

\author{
Abdurrachman Faridi ${ }^{a, *}$ \\ ${ }^{\mathrm{a}}$ State University of Semarang, Indonesia
}

\begin{abstract}
The teaching of English as a local content subject in elementary schools in Central Java is aimed at giving students the skills to verbalize simple sentences. Students are also expected to be able to accommodate sociocultural aspects of their environments in their learning. However, some of the teachers still find it difficult to understand the place of English as a local content subject in the curriculum. Something should be done to update the teachers' abilities to cope with the curriculum, especially to develop English education instructional materials. This study focuses on five primary objectives: (1) to further investigate the model of teaching English as a local content subject at elementary schools in Central Java; (2) conduct a needs assessment for teaching English; (3) evaluate teachers' abilities to develop materials in English; (4) design a model of materials for teaching English; and (5) evaluate the effectiveness of the model. Two hundred English teachers from 200 elementary schools in Central Java participated in this study and were selected using a purposive random sampling method. The study was supported through coordination efforts of the Central Java Provincial Office of Education. An interactive approach was used to analyze the data and help the author contact the respondents to clarify or confirm the data collected. Experimental research and expert judgments were used to test the model.
\end{abstract}

\begin{abstract}
Abstrak
Pengajaran Bahasa Inggris sebagai muatan lokal atau mulok di Sekolah Dasar di Propinsi Jawa Tengah diorientasikan pada kemampuan siswa mengucapkan kalimat-kalimat sederhana. Siswa juga diharapkan mampu mengakomodasi aspek sosial budaya dari lingkungan belajarnya. Namun, beberapa guru masih mengalami kesulitan memahami status Bahasa Inggris sebagai mulok di kurikulum. Diperlukan upaya peningkatan kemampuan guru dalam mengolah kurikulum, terutama mengembangkan materi ajar Bahasa Inggris. Ada lima tujuan utama penelitian ini, yaitu: (1) meneliti lebih jauh model pengajaran Bahasa Inggris sebagai muatan lokal di Sekolah Dasar di Jawa Tengah; (2) mengevaluasi kebutuhan pengajaran Bahasa Inggris; (3) mengevaluasi kemampuan guru dalam mengembangkan materi ajar Bahasa Inggris; (4) mendesain model materi ajar Bahasa Inggris; dan (5) mengevaluasi efektivitas model baru tersebut. Sebanyak dua ratus guru Bahasa Inggris di Sekolah Dasar di Jawa Tengah berpartisipasi dalam studi ini, yang direkruit melalui metode sampling acak bertujuan (purposive random). Penelitian ini didukung dan dikoordinasi oleh Dinas Pendidikan Propinsi Jawa Tengah. Metode interaktif digunakan untuk menganalisa data dan mengkontak responden guna mengklarifikasi data yang terkumpul. Metode eksperimental dan penilaian ahli digunakan untuk menguji model.
\end{abstract}

Key Words: English Teaching, Elementary Schools, Contextual Learning, Instructional Resources, Learning Acquisition

\section{Introduction}

The 1989 Rule of The National Education System in Indonesia made it possible for English to be taught as a local content subject in elementary schools in Central Java, Indonesia (Retmono 1992; Suhardjito and Rokhman 1999). A local content subject is defined here as the inclusion of a subject in a school's curriculum that is

*Corresponding author. Address: International Office, State University of Semarang, Sekaran, Semarang, Indonesia. Email: pakdur@yahoo.co.id. based on a community's need. A local content subject is discussed by the school committee, on behalf of the community, together with the principal before it becomes a part of the formal curriculum. There are three kinds of local content subjects taught in every elementary school in Central Java Province: (1) provincial level, where Javanese local language is a compulsory subject; (2) district (regency) level, which includes traditional dance or wood carving as a compulsory subject; and (3) school level, where English is a local content subject. While this study discusses all three levels, the following analysis focuses on the 
third level and English education in Central Java Province because it is a leader in English education in elementary schools throughout Indonesia.

English education became part of the curriculum in elementary schools throughout Central Java in 1995, with the primary objective to teach students to speak English using very simple sentences. This objective has since evolved into accommodating students' sociocultural perspectives and values, such as, developed from their families, peers, and communities (DIKNAS 1994). The Provincial Office of Education of Central Java has made many efforts to support the English education in elementary schools. For example, after implementing an English education curriculum in elementary schools as a local content subject, officials held various kinds of workshops for English teachers to understand the goals of English education and to learn how to effectively teach English.

Based on the results of an evaluation of English education conducted by Suhardjito and Rokhman (1999) elementary school practitioners-including as principals, heads of curriculum development, and teachers - had an unsatisfactory understanding of the English education curriculum. This was also revealed by a research study conducted by Astika (1996) based on random observations at selected elementary schools that provided English education as a local content subject in Central Java and Yogyakarta. The result of the research further explains there were four handicaps identified in teaching English as a local content subject in Central Java: (1) the lack of English teachers; (2) a relatively poor understanding of the curriculum and learning guidelines; (3) the unavailability of sufficient teaching materials; and (4) the insufficient knowledge of teaching methodology by English teachers.

It is important to further investigate the model of teaching English as a local content subject in elementary schools in Central Java and to evaluate the local teachers' abilities to effectively teach English because the quality of education provided can either support or discourage students' interests in learning English. Research studies by Celce-Murcia, Dornyei and Thurrell (1995) and Arikunto, Suharsimi and Vincencio (1996) show that Indonesian students are highly motivated to study English. Instrumental motivation and integrative motivation both drive Indonesian youths' interests to study English. The research revealed that students have an instrumental motivation when their intent to study English is a result of their wishes to continue to study English in junior and senior high schools, or if they can speak English with relative ease. Instrumental motivation also explains why students want to learn English to better prepare themselves for employment when they complete their secondary education.
Integrative motivation refers to how much students desire to study English for the mere pleasure or enjoyment of learning the language. However, this type of motivation is not necessarily supported by Indonesian teachers' readiness to teach English, the availability of interesting and appropriate instructional materials, or the application of a learning development model that is relevant to the students' learning needs. Suhardjito and Rokhman's (1999) research also found various handicaps in teaching and learning English as a local content subject in Indonesian elementary schools. The most notable handicaps included (1) teachers' lack of sufficient qualifications, where some teachers did not have English education training and/or experience, but were trained in other subject areas like religion and civics; (2) curriculum, because the difficulties teachers faced in teaching English who were not educated in English education; and (3) the lack of available instructional resources like audio visual aids such as tape recorders or CD players. Instead, a majority of teachers used the "chalk and talk" method. These handicaps were typically related to the teachers' lack of competence in the teaching and learning processes. Today, some English teachers do not even speak English well and are not able to choose the best teaching methods and materials to use in their classrooms. This does not benefit the students' overall learning experiences and does not support the schools' mission to provide quality English education.

Along with being tasked with implementing the school-based curriculum (KTSP), teachers' roles are becoming increasingly demanding and more complex. This is especially evident in the task of developing teaching materials (Ministry of National Education [MONE] 2006a). The complex curriculum requirements force teachers to create appropriate instructional materials. This problem becomes the primary challenge in teaching English in elementary schools in Central Java (Cunningsworth 1995; Faridi 2001). Teachers are completely responsible for developing the appropriate materials for their classes, in which they have to adjust materials according to the conditions of the schools, their students' abilities, and the students' sociocultural conditions they carry with them into the classroom (MONE 2006c). The type of materials teachers develop and how they develop them are important aspects in evaluating teachers' abilities to provide a quality English education to their students. The aforementioned problems served as the catalyst for the research study discussed in this article, which was designed with the following objectives: (1) to further investigate the model of teaching English as a local content subject in elementary schools in Central Java; (2) to conduct a needs assessment for teaching English; (3) to evaluate the teachers' abilities to develop learning resources; (4) to design a materials development model for teaching English; (5) to use the model to develop learning resources; and (6) to evaluate the 
effectiveness of the model the researcher developed based on the work of Dubin (1997). These six objectives support the larger goal of this study, to illustrate how teachers can begin to understand the place of English as a local content subject in the curriculum and how to effectively teach English as a local content subject.

\section{Methodology}

The study was implemented in three stages: exploration, model development, and testing of the model. The first stage, exploration, was based on the findings of a needs assessment conducted to map teachers' learning needs with respect to teaching English as a local content subject. Questionnaires were used as the primary means to collect data and were distributed to the participants during the first stage. A team of colleagues helped the author develop a pre-test of the questionnaire. The pre-test was administered to ten elementary school teachers as a sample in the area of Semarang, the capitol city of Central Java, to check the validity and reliability of the questionnaire.

The questionnaire was divided into five parts: personal details, education background, experience in teaching English, the difficulties or problems in teaching English, and suggestions for improving English education in their schools. Participants included 200 English elementary school teachers with varying education and experiences from 35 regencies, or cities, in Central Java. The sampling technique used was purposive random sampling, based on the coordination efforts of the Central Java Provincial Office of Education. Questionnaires were sent to participants via airmail and were completed in their classrooms and mailed back to the author using pre-addressed and stamped envelopes so the participants' anonymity could be maintained.

The questionnaire consisted of ten open-ended questions and was intended to gather as much information from the participants as possible. Example questions include (1) Do you develop the material based on the environmental need as it is stated in the curriculum?; (2) What kind of instructional aids do you use when you teach English?; and (3) What problems do you have in teaching your students using imported books? These questions were intended to check the teachers' abilities to develop instructional material with sociocultural views in mind, to find out more information about the teachers' creativity in using instructional aids, and to identify problems related to the teaching and learning process.

After one month - when the researcher received all of the 200 questionnaires constituting a 100 percent response rate-he invited 12 teachers with bachelor's degrees in English to participate in an in-depth oral interview. These participants were randomly selected from the original sample of 200 English teachers. The purpose of these interviews was to gather more indepth data and to crosscheck the results of the questionnaires, for some respondents gave unclear responses on the open-ended questionnaire. In addition, ten students from schools and cities representing each district (Karesidenan) participated in an indepth oral interview. Student participants were randomly selected and included in the study to help map the teaching learning process and the teachers' learning needs with respect to teaching English as a local content subject.

First, the teachers answered background and demographic questions, including information on their education background and work experience. Teachers also had to recall their experiences in teaching English, including the problems and difficulties they encountered in the teaching process. The interviews concluded with teachers having the opportunity to provide suggestions about how to develop teaching and learning processes in their schools. Similarly, student participants were also asked demographic questions, such as the school they attended, what classes they were enrolled in, how long they studied English, what problems they encountered in studying English, and what suggestions they had to make the English education lessons more interesting.

\section{Model of Teaching English in Elementary Schools and Teachers' Abilities to Develop Materials}

The results of the questionnaires and interviews reveal many significant conditions teachers face in teaching English. Most of the teachers still rely on textbooks as a primary teaching resource. However, the textbooks available, either from Indonesia or from abroad, are not always of a high quality nature. Even if, in rare instances, the quality of the textbooks are good, the content may not always be appropriate for the existing curriculum and the students' sociocultural environments. The result is that the process of teaching and learning English is often unsatisfactory. Students do not increase their proficiency in English with insufficient teaching resources, especially when they have to express something related to their environments. This directly contrasts with national curriculum goals, which state that students are expected to demonstrate proficient English skills for global or international communication.

Teachers also do not always write their own syllabi or lesson plans. If they do, they copy the syllabi and/or lesson plans from other teachers whose schools have completely different conditions and curriculum goals (Agustin 2004). This problem is exacerbated by the fact that some teachers do not even know how to read and interpret the curriculum or write a lesson plan. In short, teachers rarely use the curriculum and tools provided them to develop their 
own materials and pedagogical approaches to teaching. These conditions result from teachers' poor qualifications and often remain in a vicious cycle recurring state. Tarigan (1991), Parera (1996), and Sumadi (2000) state that the lack of teachers' knowledge will affect the teaching and learning process, which ultimately impacts the quality of English education provided to students. The scholars also argue that a teacher will be able to design activities, develop instructional materials, and evaluate students' learning processes more effectively when they receive formal training in the same subject they are teaching. With many English education teachers lacking formal training in English education in Central Java, teachers are generally unable to effectively perform the aforementioned tasks.

\section{Characteristics of English Teachers at Elementary Schools and Their Instructional Needs}

According to the results of the questionnaires, many English teachers, especially novice teachers, do not have a formal training in English education. Rather, some of the English education teachers are graduates from other disciplines such as religion, sports, and the arts. Generally for financial reasons, many school principals do not hire English teachers at all. Instead, they ask the teachers of core subjects to teach the English classes. Table 1 presents the education background of the teachers that responded to the questionnaire.

Table 1. Teachers' Education Background

\begin{tabular}{ccc}
\hline Education & Frequency & Percentage \\
\hline Background & 56 & $28 \%$ \\
English & 144 & $72 \%$ \\
Non English & $\mathbf{2 0 0}$ & $\mathbf{1 0 0 \%}$ \\
Total & & \\
\hline
\end{tabular}

Of the 200 teachers that responded, only 56 teachers, or 28 percent, have a formal, academic background in English education. The remaining 144 teachers, including classroom teachers, or 72 percent, were formally trained in other majors. Classroom teachers are responsible for teaching a variety of subjects, such as Indonesian, civics, science, mathematics, and history. Classroom teachers are commonly employed in elementary schools. However, subject teachers, such as those who primarily teach religion, the arts, and English are also available to teach. This is contrary to trends in employment opportunities where some Indonesian graduates with formal, academic training in English education find it difficult to find a job. Table 2 outlines teachers' status. Since classroom teachers teach a variety of subjects, they have different kinds of education backgrounds. Classroom teachers account for 145 , or 72.5 percent, of the 200 teachers. In comparison, only 55 or 27.5 percent are English education teachers.

Table 2. The Teachers' Status

\begin{tabular}{ccc}
\hline Teacher's Status & Frequency & Percentage \\
\hline Class Teacher & 145 & $72.5 \%$ \\
English Teacher & 55 & $27.5 \%$ \\
Total & $\mathbf{2 0 0}$ & $\mathbf{1 0 0 . 0} \%$ \\
\hline
\end{tabular}

The teachers identified a variety of professional needs in the questionnaires and the interviews. After crosschecking the results of the questionnaires and the interviews, three needs became paramount. First, almost 30 percent of the teachers did not know how to properly write lesson plans or syllabi due to their different education backgrounds and training experiences. Second, the textbooks used in schools, which accommodate sociocultural aspects of education, are not readily available to purchase and use in classrooms. Finally, approximately 51 percent of teachers attempted to accommodate songs, games, and local folktales for English classes in elementary schools in Central Java. However, due to their lack of knowledge in designing materials, they simply translated Javanese songs, games, or folktales into English. For example, students sang English songs in Javanese tunes or translated local idioms into English. This simple translation effort does not teach students the broader context of English and the Western culture.

\section{Design Model for Learning Resources}

The quality of English education is partially a result of the quality and effectiveness of the teachers' and students' attainment skills. Another variable is the type of supplemental instructional materials teachers use and the quality of such materials (Finocchiaro and Brumfit 1983). Based on the findings above, the author designed a model for developing instructional materials for English education in elementary schools in Central Java that is based on students' sociocultural views to facilitate children's learning. The development of such a model and subsequent instructional materials is accomplished by following the six rules suggested by Dubin (1987): (1) reference of the development, which is mainly based on Javanese culture; (2) content of the existing materials; (3) organization of the new materials; (4) development of the materials; (5) presentation of the materials; and (6) evaluation of the materials. This is accomplished by using 
materials based on students' local environments, such as songs, games, and folktales. In short, the model of materials (see Figure 1), teachers' competence, and the students' learning process all contribute to the output and are indicators of the success of the English education process. The Development Model of English Teaching, inspired by the work of Dubin (1997), is expected to simulate discourse on how teachers' pre-service education, overall competencies, and choice of supplemental instructional materials they utilize prepare them to effectively teach English. The input variables listed in Figure 1 are aspects that are a part of the larger task, teaching English. The model is also intended to maximize the outputs: enhancing teachers' competencies and helping

Figure 1. Materials Development for English Instruction Model

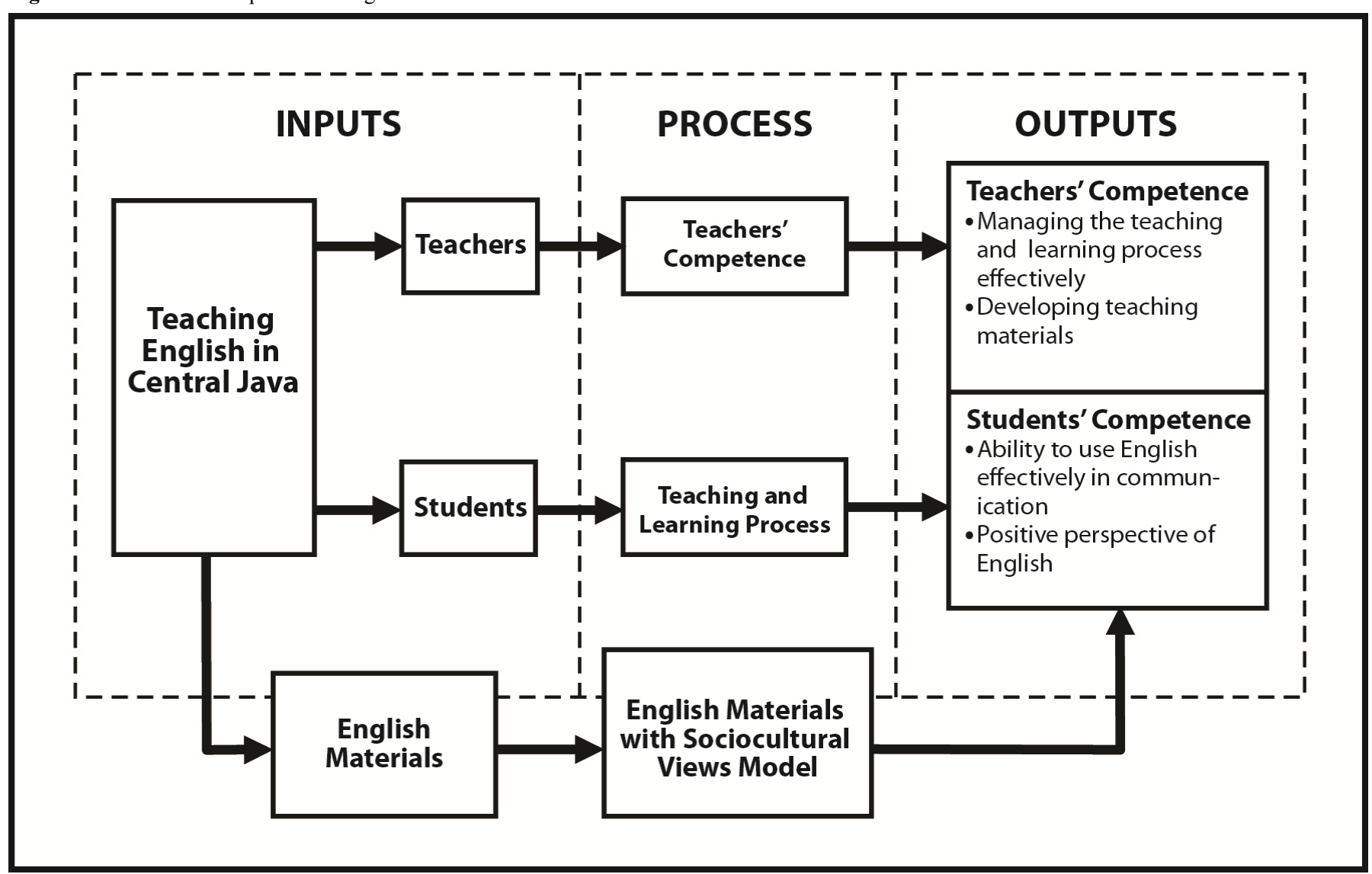

students use language communicatively. Furthermore, by providing a model focused on the development of materials for how to provide a quality English education for students in Central Java, this model provides an effective perspective of teaching English in elementary schools in Central Java.

The Materials Development for English Instruction Model as a local content subject in Central Java is based on the English learning strategy advocated by Hammond (1992). This learning strategy has four cycles: (1) Building Knowledge of the Field, where teachers provide brainstorming opportunities or questions related to the topic s/he is going to explain; (2) Modeling of the Text, where the teacher provides an example pronunciation or grammar model related to the text; (3) Joint Construction of the Text, in which teachers ask students to reconstruct, make sentences or retell the story based on the text provided; and (4) Independent Construction of the Text, in which teachers ask students to construct their own sentences or stories based on the model given in the text. The presentation of the language skills and the subsequent learning process are carried out using an integrative approach in which each language skill is not presented 
explicitly. Instead, two, or even three, language skills are sometimes presented at the same time for the sake of practicability. The material developed covers four competences: listening, speaking, reading, and writing. In its development, the instructional material must deal with the students' daily activities in the family, school, and society, and must also be connected to the sociocultural aspects of customs and traditions.

\section{Effectiveness of the Model}

In order to evaluate the effectiveness of the model, the author conducted an experimental activity at three elementary schools: Sekolah Dasar (SD) Sompok, a state school; SD H. Isriati, an Islamic private school; and SD Theresiana, a Catholic private school. The experimental activities began by pre-testing the model in the three schools with students to gage their basic knowledge of English. Two Grade 5 classes from each school participated in the experimental activities. One class was the experimental class, while the other was the control class. Grade 5 students were selected as the participants because they already had one year of English education. This is the appropriate amount of knowledge to be evaluated. In comparison, Grade 4 students only have one month of English education, while students in Grade 6 spend a significant amount of their time preparing for the final national exams.

Each class had between 30 to 35 students. The experimental group was presented with three treatments using the model material. The material contained sociocultural information in the form of games, songs, and folktales. In contrast, the control group was taught with the general, unmodified material from textbooks. Post-tests were administered to both groups. The students' results of the post-tests were scored and ranked from 0 to 100 . The results of the experiments reveal that there are distinct differences between the results of the English pre-tests and post-tests from the control classes and the experimental classes from the three elementary schools (see Figure 2). SD Sompok received a 74.5 score for the control group and 88.7 for the experimental group. SD H. Isriati had a score of 79.8 for the control group and 89.8 for the experimental group. At SD Theresiana the control group scored 78.6 and 92.6 for the experimental group. Based on the results of the test from the sample schools, there is a difference in the quality of English education between the control and the experiment groups. In other words, the results show that the model material is effective in teaching English as a local content subject at elementary schools in central Java as compared to traditional methods which take little regard for local sociocultural elements in the curriculum.
Figure 2.Comparison between Control and Experimental Groups

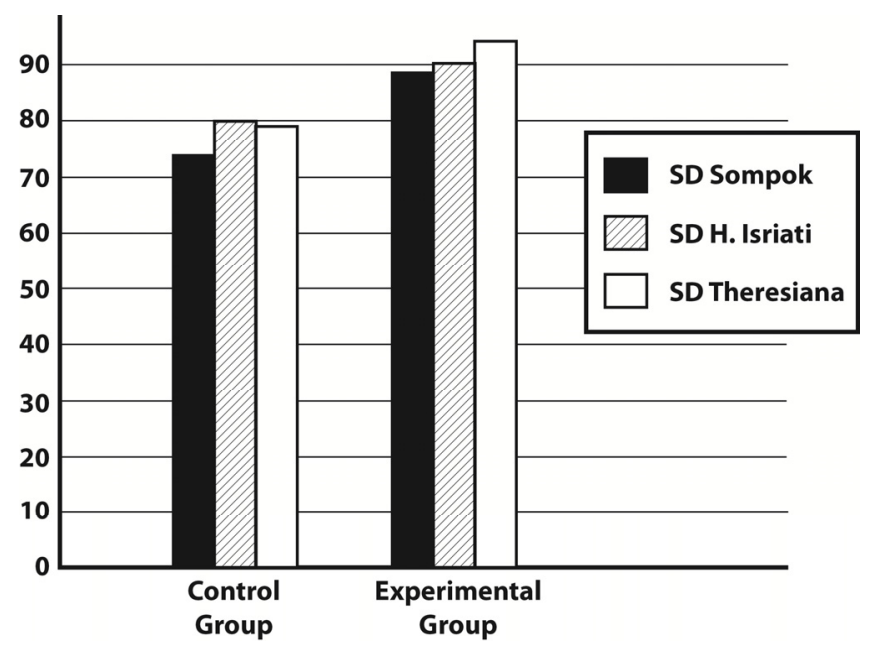

Two content area experts-Emalia Iragiliati, an English Lecturer at the State University of Malang, and Christian Jeanny, a fellow from RELO who is teaching at the State University of Semarang-were consulted about the results of this study. Both experts suggested improving the material used in the model in regards to spelling, grammar, and vocabulary. They also suggested that cultural aspects, like having students raise their left hands, were considered to be impolite by elementary school teachers in Indonesia. This is based on either religion or Javanese culture, where giving something, raising hands, or pointing at something using the left hand is impolite. Moreover, they suggested that native speakers, especially children, do not commonly express the English word "madam." Jeanny suggested that the writer use "ma'am" instead. In the original material, the author used the term madam for addressing female teachers. For example, when a female teacher asked students to sit down, they responded with the expression "yes, madam" not "yes ma'am." This is an example of the sociocultural perspective incorporated in the model curriculum.

\section{Conclusion and Implications}

The development model of teaching materials outlined in this study can be used as a guideline for English elementary school teachers to develop their own instructional materials (i.e., syllabi and lesson plans). Moreover, the Department of Education and Culture of Central Java Province, higher education institutions, and other institutions that provide English teaching programs should be mindful of the findings related to teachers' competence 
and qualifications. As is previously mentioned, the percentage of teachers with sufficient levels of competence and qualifications are still low in Indonesia, which negatively affects students' mastery of English. On the basis of this study, it would seem necessary to replace teachers who do not have an English education background with teachers who do have formal training in English education. If not, it is suggested that the government should hold specific training sessions to better prepare English teachers in elementary schools who do not have a formal English education training. Such training sessions can also be a process of certification for all teachers. As an alternative, it would be useful if higher education institutions and the Department of Education and Culture from the regency/city level to the province level establish a partnership with the purpose of improving the competence of English teachers.

The methodology of this research could be improved by increasing the number of participants in the sample, as well as the scope of presentation. The findings of this study are formulated in a grounded way through deductive analysis based on the current literature and evidence-based data in the field. However, this study is a case study in Central Java. Caution should be taken when attempting to generalize the findings to other regions. In order to generalize the findings, the same study, with a broader scope should be conducted. This teaching material model has not been thoroughly tested and disseminated. Therefore, it is necessary to continue to test this model by conducting further studies and evaluations. Such in-depth analysis can assist in developing a qualified model to provide a valid and legitimate guideline for enhancing English education and teaching materials used in the elementary schools throughout Indonesia.

\section{References}

Agustin, Helena. 2004. Landasan Filosofis KBK (Philosophical Base, Competence-Based Curriculum). Unpublished paper for the National Seminar on English Curriculum, Semarang, Indonesia.

Arikunto, Suharsimi, and Evelina M. Vincencio. 1996. Pembelajaran Aktif dan Kreatif (Active and Creative Learning). A Handout for Local Content Subjects. Jakarta: Departemen Pendidikan Dan Kebudayaan (Department of Education and Culture).

Astika, Gusti. 1996. "Proses Interaksi Belajar Mengajar dalam Pelajaran Bahasa Inggris di beberapa Sekolah Dasar di Jawa Tengah dan Yogyakarta" (Interaction in Teacing Learning Process in Some Elementary Schools in Central Java and Yogyakarta). Jurnal Penelitian Pendidikan Dasar 1.
Celce-Murcia, Marianne, Zoltan Dornyei, and Sarah Thurrell. 1995. "Communicative Competence: A Pedagogically Motivated Model with Content Specifications." Issues in Applied Linguistics 6 (2): 5-35.

Cunningsworth, Alan. 1995. Choosing Your Coursebook. Portsmouth, NH: Heineman.

DIKNAS. 1994. GBPP Mulok Bahasa Inggris SD di Jawa Tengah (The Teaching Guideline for English as a Local Content Subject in Elementary Schools in Central Java). Semarang: Depdiknas.

Dubin, Fraida, and Olshtain Elite. 1987. Developing Programs and Materials for Language Learning. New York. Cambridge University Press.

Faridi, Abdurrachman. 2001. "Patterns of Teaching English at Elementary School in Central Java." Master's thesis, State University of Semarang, Indonesia.

Finocchiaro, Mary, and Chistopher Brumfit. 1983. The Functional-National Approach: From Theory to Practice. New York: Oxford University Press.

Hammond, Jenny. 1992. English for Social Purposes: A Handbook for Teachers of Adult Literacy. Sydney: National Centre for English Language Teaching and Research, Macquarie University.

Ministry of National Education (MONE: Departemen Pendidikan Nasional). 2006a. The Guideline for Handout Development (Pedoman Pengembangan Buku Pelajaran). Jakarta: Pusat Perbukuan.

MONE. 2006b. The Quality Standard for English Handout (Standar Mutu Buku Pelajaran Bahasa nggris). Jakarta: Pusat Perbukuan.

MONE. 2006c. The Standard Competence and Basic Competence of English for Years 4, 5 and 6 of Elementary Schools or Islamic Elementary Schools, Curriculum 2006 (Standar Kompetensi dan Kompetensi Dasar Mata Pelajaran Bahasa Inggris untuk Kelas IV,V dan VI SD/MI Kurikulum 2006). Jakarta: MONE.

Parera, Jose Daniel. 1996. Pedoman Kegiatan Belajar Mengajar Bahasa: (Teaching Language Guideline) Landas pikir landas teori. Jakarta: PT Gramedia Widiasarana Indonesia.

Retmono. 1992. Strategi Pembelajaran Bahasa Inggris di Sekolah Dasar (Strategy for Teaching English in Elementary Schools). Unpublished Paper for English Teaching in Elementary Schools Seminar. Semarang: Indonesia.

Suhardjito and Fathur Rokhman. 1999. Model Pengembangan Motivasi Belajar Bahasa Inggris siswa SD Di Jawa Tengah. (Model of Developing Learning Motivation in English) Research Report. Semarang: Research Centre of Teaching and Educational Science Institute of Semarang. 
Sumadi. 2000. Panduan Penelitian, Pemilihan, Penggunaan, dan Penyusunan: Buku Pelajaran Bahasa Indonesia SD. (Guideline for Research, Selection, Usage and Publication for Indonesian Handout of Elementary Schools). Jakarta: Grasindo.

Tarigan, Henry G. 1991. Language Teaching Methodology 1 and 2. Bandung, Indonesia: Remaja Rosdakarya. 